\title{
The ECLA technique of programming and economists in Argentina in the mid-twentieth century ${ }^{1}$
}

\author{
Mariano Arana
}

\begin{abstract}
This article analyses the origin and development of the technique of programming of Jorge Ahumada, of the Economic Commission for Latin America (ECLA), ${ }^{2}$ and its importance for economists and economic development planning institutions. To that end, it examines the circulation of the technique in various organizations in Argentina and shows how planning gained legitimacy alongside the main economic policy debates of the mid-twentieth century, while describing the institutional circulation of experts and their texts in the country. The ECLA contribution was found to have a direct impact on local institutions, which reinforced the idea of accelerated growth with economic stability and contributed significantly to the theoretical training of economists in Argentina.
\end{abstract}

\section{Keywords}

Economic development, economic planning, ECLA, economists, training programmes, vocational training, economic history, Latin America

JEL classification

A11, B41, C61

\section{Author}

Mariano Arana holds a bachelor's degree in Economics and a specialization in University Teaching in Economic Sciences from the University of Buenos Aires (UBA), as well as a master's degree in Economic Policy from the Latin American Faculty of Social Sciences (FLACSO). He is also a researcher and teacher at the Institute of Industry of the National University of General Sarmiento (UNGS). Email: marana@campus.ungs.edu.ar.

\footnotetext{
1 A summarized version of this work was presented at the sixteenth Jornadas Interescuelas/Departamentos de Historia event, during thematic round table 106 entitled: "La planificación y el Estado argentino: agencias, expertos, modelos foráneos e impacto regional (1933-1983)". The comments from Diego Pereyra, Hernán González Bollo, Aníbal Pablo Jáuregui and the reviewing judges are gratefully acknowledged. The author alone is responsible for any errors in the text.

2 Pursuant to Economic and Social Council resolution 1984/67 of 27 July 1984, the Commission's name was changed to Economic Commission for Latin America and the Caribbean (ECLAC) to reflect its expanded scope of work.
} 


\section{Introduction}

In the early 1950s, there were several antecedents to the planning experience in Latin America, including the Soviet management methods focused on sectoral balances; efforts in the United States to study the aggregate instruments shaping the economy since the Great Depression; the French focus on investment with the aim of modernizing productive sectors; and lastly, the testing of five-year plans in Latin America. The first three approaches were studied at ECLA with a view to proposing a different type of planning. The aim of the new methodology was to evaluate and communicate possible economic trajectories based on the existing structure. The technique of planning - or programming - developed by ECLA was intended to be neutral enough to bring about decisions that would foster the transparency and efficacy of political powers. Celso Furtado considered planning as neutral as the input-output technique (1988, p. 117).

The technique of programming was a methodology developed by the Economic Development Division of ECLA, headed by Celso Furtado and including Juan Noyola, Regino Boti, Alexandar Ganz and Pedro Vuscovic. In his first decade at ECLA, Jorge Ahumada, who was part of the team led by Raúl Prebisch and who worked with the Commission until 1961, was responsible for reviewing the links between planning and economic development. With his initiatives, he proposed a novel combination of aggregate planning focused on production sectors (usually found in input-output tables) and investment planning focused on the search for selection and evaluation criteria for productive techniques and projects, with a higher level of aggregation based on the use of growth theories and aggregate macroeconomic models. The aim of the present work is to recognize the origin and development of this technique and its importance for economists and institutions responsible for economic development planning, by studying its changes in the 1950s and circulation in various institutions in Argentina.

Section II describes the origins of the technique of programming through the analysis of the initial documents on the subject. It identifies theoretical influences and problems that the technique was meant to resolve, delves deeper into the image of the economist as an aggregate planner and examines the development of these ideas in ECLA publications, while analysing technical instruments and their link to the profiles required of the economists of the time. Section III, before the conclusions, describes on the one hand, the emphasis on planning in training institutions and public management organizations in Argentina, and on the other hand, the ties with ECLA and the circulation of these ideas among economists and civil servants. In both instances, there is a focus on the importance of the founding works from an economic theory and policy perspective. The conclusion drawn is that, through the planning experience, ECLA contributed directly to strengthening the idea of accelerated growth with economic stability in local institutions and had a significant impact on the theoretical training of Argentine economists in economic development. Lastly, while it describes the institutional circulation of experts and their texts in Argentina in the mid-twentieth century, this work also shows that planning gained legitimacy alongside the main economic policy debates of the time, from a theoretical and technical standpoint.

\section{The technique of programming and project planners}

At the fourth session of ECLA, held in Mexico City in 1951, one of the points raised was the importance of technical assistance for economic development in Latin American countries, and thus the need to train Latin American economists in economic development. In 1952, the United Nations Technical Assistance Programme for Economic Development began to be implemented in Chile to train specialists, under the 
direction of Jorge Ahumada. Initially, the courses trained 12 to 14 professionals at a time, but this number later increased to more than 40 people at a time. The programme was geared towards specialists from the decision-making centres of various Latin American governments, especially ministries. It included more than 250 hours of lectures over the course of three months, as well as 130 hours of round tables and other research activities.

In his role as economist at ECLA and of the United Nations Technical Assistance Administration, Ahumada published a programme document entitled "El empleo de la contabilidad del ingreso nacional en la planificación del desarrollo económico" (1952). In that work, Ahumada made reference to "rational action" in the selection of development planning methods and objectives, although he recognized the absence of a comprehensive theory on growth and of a methodology to plan it. The technique of programming responded to the objective of achieving the maximum growth rate compatible with stability and freedom of choice for the consumer. Stability was understood as the absence of problems relating to unemployment, inflation and the balance of payments. As a methodological base, Ahumada cited The Structure of American Economy, 1919-1939: An Empirical Application of Equilibrium Analysis by Wassily Leontief (1951), which described input-output techniques, ${ }^{3}$ identified the importance of studying the gap between potential and real growth, and reviewed the contribution of some North American works (including those of S. Kutnetz, E. D. Domar, Cobb-Douglas, R. Goldsmith, P. Samuelson and W. Fellner) in the use of production functions to estimate system capacity.

Ahumada also used the Keynesian model of Evsey Domar, which explained the double function of investment (in terms of the multiplier effect, amplifier of output and of capital stock, and potential output), along with the characteristics of balanced economic growth with full employment, and which outlined the conditions of stability which ensured that growth in effective output was equal to that of potential output. This brought to light the lack of systemic guarantees of these conditions of stability and growth and the need to act on investment functions to move closer to the stated objectives. Ahumada incorporated this risk into his work by highlighting that if investment triggered a multiplier effect (positive or negative depending on the direction), it would also be a destabilizing factor and therefore, the magnitude of the multiplier would have to be reduced to achieve stability and increase savings (Ahumada, 1952). Ahumada (1951) explained that development was equivalent to the achievement of the maximum rate of income growth compatible with stability under conditions of full employment. Hence, managing investment was fundamental, as it could result in inflation or unemployment, depending on whether it was excessive or deficient.

Ahumada's interest in the role of investment in development led him to explore the selection and evaluation criteria of investment projects. He argued that public and private criteria differed in terms of the object of maximization, especially since public criteria had to consider the impact of investment on total value added, meaning that they had to incorporate the indirect effects on other areas of production (forward and backward linkages) (Ahumada, 1955).

In 1957, Ahumada participated in a conference on economic development in Latin America organized by the International Economic Association (IEA) and held in Rio de Janeiro, which brought together thinkers such as Ragnar Nurkse, Celso Furtado, Howard Ellis, Felipe Pazos, Gottfried Haberler, Theodore Schultz and Albert Hirschman, among others. Concerned with providing a prescription for investment priorities that could be used by government financial agencies, he deepened his criticism of neoclassical resource allocation criteria. He pointed out that these criteria overlooked the fact that the social opportunity cost of a commodity was represented by its price only if each factor contributed the same value in different productive uses and argued that it was necessary to replace that criterion of maximization, since, on the one hand, the various uses of factors yielded different value contributions

\footnotetext{
3 Leontief published the first edition of this volume in 1941. Although there have been works relating to input-output analysis since the 1920s, they only became well-known in the mid-twentieth century in Western academic circles.
} 
and, on the other, balance was an exceptional condition and not the norm (Ahumada, 1961; Boianovsky, 2013). The contributions of this conference were incorporated the following year into the Manual on Economic Development Projects, within the framework of the ECLATAA Economic Development Training Programme.

Ahumada feels that the application of orthodox economic theory has given undue prominence to those criteria which imply the maximization of profits (for example, the benefits-costs criterion). When this latter criterion is applied, market prices are corrected to allow for social costs. Nevertheless, it still implies maximization of profits. At the same time, the economy cannot be balanced while there is a state of equality in all directions between the prices of factors (ECLA, 1958, pp. 237-238).

However, the author warned of the impossibility of determining aggregate growth without first estimating the distribution of investment and, at the same time, this investment depended on the pace of growth in income (Ahumada, 1955 and 1961). For this reason, a suggested investment plan based on the volume of savings that would allow for a projection of output (given the historical relationship between capital and output) was needed. The task was to identify the investment needed to fulfil the plan, to estimate possible changes in demand by using the income elasticity technique and to identify sectors of change to anticipate possible development friction and imbalances (pitfalls).

The technique for making the plan compatible had to be chosen by observing the effects on all sectors with different criteria, depending on whether the objectives were to achieve specific produced quantities (or fulfil manifested needs) or a specific level of productive efficiency. The plan had to contain evidence of internal coherence to avoid shortages of goods and services, considering the parity of savings with investment, of supply with aggregate demand, and of the distribution of investment with expected changes in the demand structure.

\section{The aggregate planner}

In 1956, the Faculty of Economic Sciences of the University of Buenos Aires (FCE-UBA), under the direction of Norberto González, organized a course on development issues, which was taught by professors and researchers in collaboration with senior staff of ECLA (Chirom, 1985). As a student in 1957, Mario Brodersohn (Arana, 2015b) took the intensive ECLA course at FCE-UBA along with Adolfo Canitrot, Bernardo Grinspun and Félix G. Elizalde. The three-month programme could be followed on either a part-time or full-time basis. Most of the professors were from ECLA. Ahumada was the head of the Commission's economic area and also participated as a professor, along with the first Minister of Economy of Cuba, Regino Boti. ${ }^{4}$ Roque Carranza ${ }^{5}$ taught the input-output model and Raul Prebisch gave some lectures. A scholarship was subsequently created for a course taught by Felipe Herrera ${ }^{6}$ at ECLA headquarters in Santiago. Brodherson and Alieto Guadagni were scholarship recipients.

The year before the definitive institutionalization of economists in Argentina with the creation, in 1958, of economics degree programmes at the University of Buenos Aires (UBA), the Catholic University of Argentina (UCA) and the National University of the South (UNS), Ahumada presented a draft of the intensive course entitled "Teoría y programación del desarrollo económico" in Buenos Aires,

\footnotetext{
4 In addition to Ahumada and Boti, the ECLA courses in Latin America were taught by Manuel Balboa, Dudley Seers, Hollis Chenery, Ricardo Cibotti, John Galbraith, Aníbal Pinto, Adolfo Dorfman, Leopoldo Portnoy, Osvaldo Sunkel and Alberto Fracchia, among others (ECLA, 1961).

5 He served as Technical Secretary of the National Development Council (CONADE) of Argentina between 1963 and 1966, where he helped to develop the National Development Plan 1965-1969.

6 Minister of Finance of Chile in 1953 and President of the Inter-American Development Bank (IDB) between 1960 and 1970.
} 
to be taught at FCE-UBA between September and December 1958. ${ }^{7}$ The text was oriented towards aggregate planning through the study of techniques that combined the uses of the macroeconomics of effective demand (and its multiplier and accelerator effects) with Harrod-Domar-style growth models, linked with input-output techniques (in some cases with simpler uses, like sector models), in a context of asymmetries between centres and peripheries and structural heterogeneity in the different regions. The innovation was not only in the emphasis and ways of combining the existing toolkit, but also in the fact that the new concepts were intended to make it possible to analyse the differential characteristics of the countries of the region, since development was not understood as a spontaneous process. ${ }^{8}$ In that sense, it is possible to highlight the content of this training as a general model for peripheral economies.

The aggregate planning model included 10 parameters in a system of 22 equations and 32 variables, with data from two consecutive years. Aggregate programming involves the assessment and setting of targets for end demand of goods and services, then the calculation of the production required for each sector, in order to avoid bottlenecks. The result was reflected in a table entitled "Production budget and availability of goods and services", which not only combined the distribution of production among sectors, but also among uses (consumption, investment and other) and recipients (functional distribution of income).

In his work "Notas para una teoría general de la planificación", ${ }^{9}$ Ahumada once again placed emphasis on programming as a means of ensuring rational decision-making and on the neutrality of the technique. For the author, planning was a technique to develop policies rationally (Ahumada, 1977, p.4), whereby the planner created alternatives from which the political authority could choose. "Planning is ethically and politically neutral" (Ahumada, 1977, p. 4), so both diagnosis and planning are technical tasks. Meanwhile, he believed that setting goals was strictly political. In this work, he expressed a logical approach to neoclassical problems of resource scarcity and maximization of well-being, which resulted in problems of choice (of consumption and production, among others). The work also includes reflections on theorems and axioms regarding Kenneth Arrow's paradox or impossibility theorem.

From its launch until 1956, the ECLA programme trained 187 economists from Latin America, 1 from Egypt and one from Iran -60 in Santiago and 80 in Bogotá in 1955 and 49 in Rio de Janeiro the following year. Eight-month programmes were also conducted in Santiago for specialists granted scholarships (ECLA, 1957). By 1958, 93 participants had already been trained in Santiago, 72\% of whom were economists, while the rest were engineers or agronomists. Eight participants were from Argentina (ECLA, 1959b). From 1955 to 1961, ECLA trained 1,087 participants in 15 intensive courses outside Chile. Two courses were conducted in Argentina with a total of 141 participants. The intensive course launched on 20 September 1958 at FCE-UBA had 33 full-time students and 39 observers. In 1966, the programme included 1 basic planning course, 4 special courses (on education, housing, health and economic development, and planning for labour leaders) and 10 intensive courses across the countries of the region, which were taught to roughly 700 scholarship holders (ILPES, 2012a).

\footnotetext{
7 This course was also taught in 1967, when its validity was recognized within the training programmes of the Latin American Institute for Economic and Social Planning (ILPES). In 1958, ECLA also published its Manual on Economic Development Projects.

8 These new concepts include attempts to quantify potential output and evaluate "reproducible tangible wealth" (productive assets subject to depreciation) as a unit of capital intensity. In addition to the uses of the input-output table, price and income elasticities, the trend in the terms of trade and the fundamental macroeconomic equation, social and individual maximization criteria were differentiated in investment project evaluations.

9 The text reprinted by ILPES in 1977 is taken from Cuadernos de la Sociedad Venezolana de Planificación published in 1966. However, there is a version published by the Centre for Development Studies (CENDES) of the Central University of Venezuela in February 1962, which was used for an internal seminar on planning given by Professor Luis Lander. The course on planning theory and practice taught by Carlos Mattos at ILPES in 1984 also included references to this text.
} 


\section{Aggregate, sectoral and regional planners}

In 1953, ECLA published the "Preliminary study on the technique of programming economic development", which is a methodological reflection of the Economic Survey of Latin America and the Caribbean published by the Commission since 1949. It had been outlined at the fourth session of the Commission under the title "Theoretical and practical problems of economic growth" which recognized the need to adopt development programmes and mentioned the theoretical elements for assessment and the difficulties faced by peripheral countries. In that instance, it was said that it was necessary to take advantage of the knowledge developed in the central countries to theoretically interpret economic development problems and to train economists in Latin American countries:

With this purpose in mind, it would be necessary to organize seminars in which the ECLA economists, together with competent directors appointed for this purpose, might dedicate a part of their time to pooling their knowledge for the purpose of training other economists [...]. It is not intended to replace the many colleges or Faculties of Political Sciences existing in Latin American universities, nor to compete with them, but rather to co-operate with these institutions, supplement their task and work hand in hand with their graduates who, having already some experience of Latin American problems and concrete responsibility in economic planning, desire to specialize themselves in problems of development. The seminar courses envisaged would be for postgraduates and by reason of their nature, it is presumed that they would be limited to a relatively small number of persons (ECLA, 1951, pp. 112-113).

In 1955, ECLA published Analyses and Projections on Economic Development, part one of which included "An introduction to the technique of programming". The programming technique identified common variables in Keynesian models of macroeconomic growth, but added an emphasis on international economic relations that was consistent with the Commission's concerns. In addition, it distinguished early on the problems of measuring the volume of capital and the use of techniques. Thus, it referred to what was later called the "capital controversy" or the "Cambridge controversy", which aimed to discover inconsistencies in the fundamental propositions of the neoclassical theory of capital in its aggregate form. ${ }^{10}$

From the Commission's perspective, planning had to be focused first on the general, then on the specific. These two phases were called aggregate and sectoral projection, respectively, ${ }^{11}$ and the first phase included the variables of the fundamental macroeconomic equation. Starting with aggregate projections answered any questions about the investments required to achieve a specific rate of growth in output. That rate was the target variable and was used to determine what was needed achieve the goal. It was argued that starting with a sectoral planning approach meant the growth rate could not be determined beforehand, and therefore could not serve as the target variable, resulting in the failure to optimize efforts and resources. ${ }^{12}$

The work highlighted the neutrality of the technique, which would make it possible to distinguish between present and future consumption, as well as the share of foreign capital and public spending which, according to the Commission, were ways of financing growth in activity in light of stronger future consumption. It was said that:

\footnotetext{
10 This text likely contributed to the debate about the problem of measuring capital, how it was linked to the trend in output and the reversal of techniques from the periphery. See Boianovsky (2013) for more details on the theoretical debate.

${ }^{11}$ Once these first two phases were in place, both the economic policy to be followed and the administrative organization for implementation had to be determined. Both phases fell outside the scope of the document.

12 Aggregate planning would generate: (i) the trend in income, (ii) the distribution of income between consumption and saving, (iii) the amount of investment needed and financing of this investment and (iv) the capacity to import and substitute. Subsequently, sectoral planning would reveal: (v) future demand of the different goods (consumer, intermediate, capital), (vi) the distribution of required investment, (vii) end demand and imports at the sectoral level, (viii) export possibilities and (ix) information on labour productivity levels.
} 
The role of the expert is to submit the different alternatives with all objectivity (...). This attitude of impartiality in the technique of programming is not only laudable in defining functions; it is also commendable inasmuch as it strengthens the moral authority and increases the powers of persuasion of those drawing up the programme (ECLA, 1955, p. 9).

Sectoral planning consisted of breaking down the aggregate estimate of demand by sector, estimating sectoral growth by calculating the respective income elasticities of demand -in accordance with projected increases - , studying the possibilities of substituting imports, and then analysing the compatibility of supply-side compliance.

According to Ahumada (1966a), development planning required the training of aggregate programmers, whom he called project planners. Other requirements were coordination personnel with a profile in statistics and management, given their involvement in the different stages of the process, and lastly, sectoral planners, for example agricultural, industrial, transport and mining specialists, among others. Although the economists had to be in charge of aggregate programming, sectoral planners had to have profiles linked more strictly to the activity (for example engineers and agronomists). Ahumada (1966a) recognized that economists in Latin American universities in the mid-1960s were not receiving such training, and supported the idea of institutionalizing the development planning profession.

\section{Training and management with the technique of programming}

In 1957, FCE-UBA created an advisory committee to develop a new curriculum. In Revista de Ciencias Económicas, the committee published two drafts of the reform: one by Enrique Reig and the other by the Curriculum Committee (Reig, 1958). The new School of Economics (which offered a bachelor's degree in Economics and a doctorate) included the Seminar on Economic Development Policy ${ }^{13}$ proposed in one of the drafts. Core content included the study of development planning and evaluation of investment projects, economic development financing, sectoral planning and localization, organization of development planning and understanding the economic development problem in Argentina. The programme of the 1963 seminar (UBA, 1963b) included the core content formulated years earlier and was run by Leopoldo Portnoy. ${ }^{14}$ Its learning objectives included a focus on modelling, goal and strategy setting, evaluating investment timing and alternatives, project management and calculations. Not only was Ahumada's programme included, but sections were exclusively focused on reviewing the aggregate planning model and examining sectoral planning problems. The seminar bibliography included references to both econometrics (L. Klein, F. Toranzos and R. G. D. Allen) and development planning (J. Ahumada, J. Tinbergen, A. Hirschman, United Nations and H. Chenery) and other authors discussing capital accumulation (R. Nurkse and N. Kaldor). Some contents of the seminar were updated in 1967, including economic development planning, which focused on authors such as Arthur Lewis, Walt W. Rostow and Jan Tinbergen (UBA, 1967). It was not until 1973 that the subject of economic development began to reflect the influence of the dependency theory, far removed from the concerns about measuring development typical of the political and university context (UBA, 1973).

\footnotetext{
${ }^{13}$ Although some economic development themes were included in parts of the existing curriculum (curriculum D of the Seminar on Economic Development Policy), there was no equivalency between the new curriculum and the old one (CECE, 1962). The programme of the third economics course of 1958 at FCE-UBA (still in curriculum D) expanded the themes of the unit on economic development to include "Development planning", "Short- and long-term planning" and "The balance of payments and foreign investment". The curriculum reform drafts of 1958 included the "Seminar on economic development and contemporary economic structure".

${ }^{14}$ Portnoy (1918-1997) was a public accountant and held a doctorate in Economic Sciences from UBA, where he served as lecturer and dean. He taught the ECLA programme offered at FCE-UBA.
} 
In 1960, the Federal Investment Council of Argentina organized an intensive training course on economic development problems. Héctor Grupe and Oscar Cornblit wrote and published a unit on regional planning that included themes specific to their areas of expertise (transport, location, agglomeration and agrarian studies, among others). Alfredo Eric Calcagno (Arana, 2018) said that he not only took the ECLA course while he was a student at FCE-UBA, but he also travelled to Chile when he was the Secretary-General of the Federal Investment Council to request permission from Raúl Prebisch to teach the course at the Argentine institution. Prebisch agreed, and also offered to collaborate by providing ECLA materials and staff to teach the course. Hence, the intensive course was offered in 1960 by the Department of Graduate Affairs at FCE-UBA. ${ }^{15}$ The syllabus included the development of economic development planning instruments, and the main text used was the one written by Jorge Ahumada in 1959 for the UBA course (Cuello and Tandeciarz, 1964). Different planning models were presented for closed and open economies, on the basis of macroeconomic factors, combined with sectoral estimates of national accounts (of the agricultural, industrial and services sectors) and classical growth theory instruments (capital-output ratios, depreciation rates and capital stock). Unconventional modelling elements were also included, such as terms of trade coefficients and profit remittance indicators. Planning consisted of simple requirements regarding the assessment of compiled variables and the setting of probable and desirable targets, followed by the review of the distribution of growth compatible with the components of aggregate demand and production sectors. In this way, programming gave rise to the national budget, which meant, at the aggregate level, what the fiscal budget meant for public sector projections and intentions. The same course was taught within the framework of the Department of Graduate Affairs in 1963 by Carlos A. García Turdero and was continued for at least two more years. ${ }^{16}$

\section{Objectivity, neutrality and control}

In December 1959, academic status was granted to the Institute for Statistics and Applied Mathematics Research, which had been created two years earlier at FCE-UBA. Some of the most representative examples of the Institute's work are the papers entitled "Modelo de crecimiento económico del tipo lineal-logarítmico con tasa evolutiva", "Metodología para el modelo sectorial de crecimiento para la economía argentina" and "Sobre la cuantificación del progreso tecnológico en un país en desarrollo", along with the seminar Modelos de Expansión Económica Equilibrada. Another sectoral economic planning model was developed by Carlos Eugenio Dieulefait (1958). ${ }^{17}$ In his work, he used the contributions of Leontief to develop a mathematical model that integrated all national sectors by using the methodological recommendations of ECLA to save on the costs of use of electronic calculation equipment. Thus, he tried to set end demand targets to find out the intermediate requirements of each sector. The article helped to disseminate modern planning techniques associated with the idea of controlling the production process.

Several mathematical models related to growth and distribution problems were published in Revista de Ciencias Económicas, such as the linear model of balanced economic expansion by Fausto Toranzos (1962), ${ }^{18}$ which, based on ratios expressed in the Leontief model, highlighted that the problem of development planning was determining the expansion of end demand that would trigger stronger

\footnotetext{
${ }^{15}$ When Álvaro Alsogaray became the Minister of Economy of Argentina in 1959, Mario Brodershon moved to the province of Buenos Aires, of which Aldo Ferrer was Minister of Economy and Norberto González led the Economic Planning Board. González used the course developed by ECLA and taught economic planning, and Brodershon introduced practical work. Both replicated this model in graduate courses in 1960 at FCE-UBA, where Juan C. Gómez Sabaíni and Raúl Cuello studied (Arana, 2015b).

${ }^{16}$ FCE-UBA produced publications in 1964 on themes such as public accounting and input-output tables prepared by the Department, and the material was reprinted the following year (UBA, 1964 and 1965).

17 Dieulefait, born in 1901, was the National Director of Statistics and Census Research in Argentina in 1946.

18 Toranzos was born in 1908, obtained a Doctor of Sciences in Physics and Mathematics and was a member of the Curriculum Committee that created the degree in 1958. He served as lecturer of Statistics at FCE-UBA.
} 
growth in national output subject to the supply conditions of production factors. Thus, the problem with the development process was maximizing national output with available resources, and therefore was a problem of linear programming.

In December 1961, the Association of Economic Science Graduates presented a cycle of conferences on the economic situation of Argentina, with the participation of Carlos Moyano Llerena, Francisco García Olano, Manuel San Miguel, Leopoldo Portnoy, Federico Pinedo and Adalbert Krieger Vasena. San Miguel and others (1961) suggested that structural imbalances would not be solved with stabilization policies. Instead, they pointed out that harmonious and accelerated development through the use of programming techniques would make it possible to accelerate growth, improve productivity, increase basic social capital (transport, communications and energy), improve the organization of businesses and, in so doing, mitigate the propagating effects of inflation (price and wages), thus reversing the depressive effects of the fall in the terms of trade.

The idea of control of the development process was included in almost all the interventions in this conference cycle. At that time, the economists' inventory included linear programming techniques, calculation of technical coefficients and demand elasticities, assessment of the impact on the balance of payments, calculation of the need for external financing and cost estimates for major investment projects. According to San Miguel and others (1961), these were of "an eminently neutral character".

\section{The uses of the technique of programming}

In 1956, Manuel Balboa and Alberto Fracchia worked on a paper entitled "El capital fijo renovable de la República Argentina en el período 1935-1955", ${ }^{19}$ which was to be presented the following year at the fifth General Conference of the International Association of Research in Income and Wealth, in Arnhem, Netherlands, and was published in 1959 in Desarrollo Económico: Revista de Ciencias Sociales (Balboa and Fracchia, 1959). ${ }^{20}$ Dedicated to the study of social accounting issues, in 1957 Balboa included the study of "general schemes of social accounts and economic models for the whole economy" (Besa García, 1992, p. 3) in his economic statistics classes in Santiago. The following year he published "La utilización del modelo de insumo-producto en las proyecciones de la economía argentina" in Desarrollo Económico: Revista de Ciencias Sociales (Balboa, 1958), a work which would be used that same year in one of the most important texts of the time: "El desarrollo económico de la Argentina", published by ECLA (1959a) as part of its series Análisis y Proyecciones del Desarrollo Económico, begun in 1955. In fact, its initial volume was precisely "Introducción a la técnica de programación". The work included data on 23 productive sectors and focused on explaining the dynamics of imports and the integration of sectoral plans in aggregate programming (ECLA, 1959a). Balboa's contributions within the framework of ECLA continued throughout the 1960s, aimed at the application of these techniques in various countries and the production of support material for the courses in which he participated (Besa García, 1992). Balboa presented a paper on the promotion of import-substitution policies at the Regional Conference for Income and Wealth Research in Rio de Janeiro, projecting three growth scenarios for the period 1962-1967. The technique of programming, together with the input-output model, served to analyse the intersectoral structure and the consequences of end demand projections (Balboa, 1960).

\footnotetext{
${ }^{19}$ An English version of this document was published in The Measurement of National Wealth (see Balboa and Fracchia, 1959).

20 In 1952, Balboa was a senior adviser at the then Ministry of Economic Affairs, headed by Alfredo Gómez Morales. In 1955, he participated in the joint group of the Government of Argentina and the United Nations for economic development planning. He prepared the volumes of Contabilidad social published by ILPES in 1963 ([online] https://repositorio.cepal.org/handle/11362/33203), which had been used since 1961 in the Joint ECLATAA Economic Development Training Programme. Fracchia worked at the Central Bank of Argentina, the Federal Investment Council, CONADE and the National Institute of Statistics and Censuses (INDEC). He was a professor at the University of Buenos Aires (UBA) and participated in the ECLA training programme as a professor of Social Accounting. Both are considered the initiators of national accounts in Argentina.
} 
One year after it was founded in 1962, the Argentine National Development Council (CONADE), together with Ahumada, produced the publication of the development theory and planning course. This was one of the first records of the training provided by the institution, which had been created in 1961 when the government was headed by Arturo Frondizi. CONADE worked with several local and external institutions. The programme of collaboration with ECLA on national accounts was led by Alberto Fracchia, while another on taxation was conducted by Federico Herschel. Manuel San Miguel and Carlos Eugenio Dieulefait, among others, served as advisers in the creation of the institution. San Miguel ensured continuity when the agency was restructured during the government of Arturo Illia, as Roque Carranza became the new Executive Secretary, supported by Bernardo Grinspun (Jáuregui, 2013). They were all linked to FCE-UBA and had participated, in some cases, in the preparation of articles, and in others, in the development planning training carried out a few years earlier. It is not surprising, as Jáuregui (2014) points out, that Roque Carranza wanted to take a technical approach to economic management, which, contrary to the Frondizi approach, was closer to "ideas of balanced growth" (p. 150).

Although there was continuity in terms of the participating officials, De Pablo (1995, p. 147) points out that Carranza made no mention of the use of input-output tables in the aggregate projections of the National Development Plan 1965-1969. He also indicates that the documents produced during San Miguel's tenure were not used either. At CONADE in 1962, the technology used for calculations was based on rectangular spreadsheets and on manual calculators (Facit and Olivetti) and electric calculators (Friden and Olivetti). A simple regression of 30 observations took several hours, with no possibility to verify calculation errors easily. De Pablo remembers that the "terribly impressive" table (the input-output table of 1953) was a huge sheet of paper stuck to the wall, and included calculations of intermediate requirements made by Clementina, the Mercury model computer that had been running at the University of Buenos Aires Faculty of Exact and Natural Sciences since 1961. ${ }^{21}$

At the first annual meeting of the Argentine Association of Political Economy (AAEP), held in the city of Río Tercero in 1964, the members of CONADE, Julio Berlinski, Faustino González, Clemente Panzone and Jacobo Rabinovich, ${ }^{22}$ published a document on the projection method followed within the framework of the development plan managed by that institution (Berlinsky and others, 1964). The work showed a planning sequence similar to those of the technique of programming. First, macroeconomic projections were made using a model of 7 equations with 16 variables and parameters, the aim of which was to set the growth rate of output and analyse the investment and external sector requirements that would make it possible to meet the target. Subsequently, the production possibilities of the sectors were analysed by selecting a sample of 11 relevant sectors within industry, transport and energy (the remaining sectors had no systematic information and were difficult to model). The work suggested that the particular attention paid to the external sector and to import substitution was evident in all programming technique documents and therefore did not refer to the intersection of actual estimates with the financial area. ${ }^{23}$

In 1967, the Centre for Economic Research at Argentina's Torcuato Di Tella Institute (ITDT) published its working paper number 39, entitled "Utilización del modelo de insumo-producto como instrumento de proyección en la Argentina" (Brodersohn and Guisarri, 1968), which evaluated the capabilities of four projection techniques for economic activity: techniques based on the input-output table (in its 1953, 1960 and 1963 versions), multiple regression, expansion of gross domestic product and expansion

\footnotetext{
${ }^{21}$ In order to finish his master's thesis at Harvard, and with the help of staff from the Institute of Calculus and a mathematician, Mario Brodersohn made an appointment to use Clementina and had to wait three months to invert an input-output table comprising 20 rows and 20 columns. Mathematical economists such as Arturo O'Connell and Roberto Frenkel worked at the Institute of Calculus in the 1960s.

22 They published their work the following year in Desarrollo Económico: Revista de Ciencias Sociales. As De Pablo (1995) recalls, Faustino González was in charge of the aggregate programming sector, in which the best professionals of CONADE worked.

${ }^{23}$ Although the intensive courses included modules on monetary policy, the absence of references to capital movements and interest rates in all the literature reviewed is notable.
} 
of end demand. Through this research, it was concluded that the first two techniques achieved much lower predictive margins of error than the last ones. In the case of Argentina, multiple regression had the advantage of generating much lower production costs and achieving better overall estimates. However, paradoxically, the results of the input-output technique were more accurate the longer the projection period. The work was an extension of the CONADE exercise on the sensitivity of the 1960 input-output table coefficients, which had concluded that the use of the technique for projection was reliable despite its weaknesses (Brodersohn and Guisarri, 1968). Like their colleagues, Osvaldo Fernández Balmaceda, Reinaldo Félix Bajraj, Guillermo Calvo and Julio Alberto Piekarz of CONADE presented their research at the first AAEP conference in 1964, and it was published the following year in Desarrollo Económico: Revista de Ciencias Sociales.

\section{Concluding remarks}

This paper explored the development and importance of the technique of programming for economists and economic development planning institutions during the two decades following its creation in 1952. The main transformations of this technique and its circulation in different institutions in Argentina were studied in a context of great changes in the field of indicative planning and ideologies in the region.

Firstly, we should note the emphasis placed on the achievement of planned, accelerated and stable growth, which introduced the documents discussed into the debates of the late 1950s on balanced and unbalanced growth, led by Ragnar Nurkse and Albert Hirschman, respectively. This approach was also in line with the use of new calculation techniques and technologies. Linear programming, electronic calculators and computers (mainly for use on input-output tables), together with the possibility of exploiting old data with new tools and building other interpretations from them, fed experts' confidence in the ability to conduct the economic process rationally. This rationality was expressed in the use of "neutral" techniques, which ensured the researcher's objectivity, so that it was possible to believe that if the results were well calculated, the identified goals could be met. The expert had to offer various economic paths to meet the social goals selected by the politicians.

Although the technique was initially based only on practice and theories were scarce, as the years went by, the search for conceptual definitions and refinements of the method led, in Ahumada's case, to the outline of a general theory. The ideas of renowned foreign economists such as John M. Keynes and Wassily Leontief frequently appeared in writings on planning: on the one hand, Keynesian theoretical tools, then linked to orthodoxy in English-speaking countries, and, on the other, Leontief's technical instruments, which expanded Keynesian macroeconomics and allowed it to be applied to both central and peripheral countries. When Ahumada tried to extrapolate his planning practice to a general model of Latin American economies, he also made use of Arrow, a general equilibrium theorist and one of the most prominent economists of neoclassical theory (Ahumada, 1977). The overall planning of central macroeconomic controls, the mesoeconomic planning of the input-output table, the selection of investment techniques and projects, and the governance of new equation models helped to refine calculations, sharpen the focus and place greater confidence in the technique. Although Jorge Ahumada, as an ECLA economist, engaged with these central texts of Western political economy and had creative ambitions in that regard, he does not seem to have gained a great deal of recognition in the discourses on modernization through development planning or even in Latin American economic thought. However, the impact he had at the time appears to be significant enough for him to be included in the social research agenda of the economic past.

In addition to highlighting Ahumada's theoretical contributions and references -creative capacity, ideological insertion and technical uses -, the second part of this paper refers to his role in the institutional context. ECLA, through the courses mentioned, sought to complement the training 
received by economists in universities and public bodies, encouraged the training of aggregate and sectoral planners, granted scholarships to specialists from decision-making centres and established fluid dialogues with government authorities, universities and experts from all over Latin America.

In the specific case of Argentina, training in planning circulated in courses, subjects and curricula of FCE-UBA, professional associations (AAEP and the Department of Graduate Affairs), publishers (Editorial Universitaria de Buenos Aires (EUDEBA) and ECLA), the national government (CONADE and ministries) the provincial government (the Federal Investment Council) and specialized journals (Revista de Ciencias Económicas and Desarrollo Económico: Revista de Ciencias Sociales). In this way, they influenced curriculum reforms for economists, while acting as postgraduate training institutions in a region where such specializations were virtually non-existent. In the total absence of development planners, ECLA developed several training courses. All this thematic breadth generated debates, research, publications, jobs and policies. The training of specialists and the contribution to development plans appear to be the two major contributions.

By 1972, the social and political problems associated with planning were already evident, and ILPES itself acknowledged excessive confidence in development plans (ILPES, 2012b). Neither the theory nor the planning technique was questioned, but rather the difficulties imposed by the political processes. From then on, emphasis was placed on adapting planning mechanisms to the particular circumstances of each country, but their importance to the technical-administrative system of the State was maintained. These configurations of techniques, theories and instruments were combined with the circulation of specialists in key institutions for the training of economists and public policy in Argentina, which spread the ideas and practices contained in ECLA texts on development planning in Latin America. This not only broadened the discussion of ideas, but also contributed to obtaining new information for the economic study of the region.

\section{Bibliography}

Ahumada, J. (1977), "Notas para una teoría general de la planificación", Project Documents, Studies and Research Papers (INT-0173), Santiago, Latin American and Caribbean Institute for Economic and Social Planning (ILPES).

(1967), "Teoría y programación del desarrollo económico", Cuadernos del ILPES, vol. 1, No. 1, Santiago, Latin American and Caribbean Institute for Economic and Social Planning (ILPES).

(1966a), "Necesidades de formación del personal de las instituciones para el desarrollo económico", Revista Mexicana de Sociología, vol. 28, No. 1.

(1966b), "Notas para una teoría general de la planificación", Cuadernos de la Sociedad Venezolana de Planificación, vol. 4, No. 4-5, Caracas.

(1962), "Teoría y programación del desarrollo", Buenos Aires, National Development Council (CONADE). (1961), "Investment priorities", Economic Development for Latin America, H. Ellis and H. Wallich (eds.), London, Palgrave Macmillan.

(1959), "Discurso del doctor Jorge Ahumada en el acto de clausura del Curso Intensivo de Capacitación en Problemas de Desarrollo Económico", Revista de Desarrollo Económico, vol. 2, No. 2.

(1958), Teoría y programación del desarrollo económico, Buenos Aires, University of Buenos Aires (UBA)/ Economic Commission for Latin America (ECLA).

(1955), "Preparación y evaluación de proyectos de desarrollo económico", El Trimestre Económico, vol. 22, No. 87.

(1952), "El empleo de la contabilidad del ingreso nacional en la planificación del desarrollo económico", Project Documents, Studies and Research Papers (INT-1749), Santiago, Economic Commission for Latin America (ECLA), November.

(1951), "Desarrollo económico y estabilidad", El Trimestre Económico, vol. 18, No. 71.

Arana, M. (2018), "Entrevista a Alfredo Eric Calcagno", October, unpublished. 
(2015a), "En el núcleo de la edad dorada del desarrollo: la Revista de Ciencias Económicas, UBA (1958-1963)", Master's thesis on political economy, Buenos Aires, Latin American Faculty of Social Sciences (FLACSO). (2015b), "Entrevista a Brodersohn, Mario S.", May, unpublished.

(2013), "Entrevista a Arturo O'Connell", July, unpublished.

Balboa, M. (1963), "Construction and use of input-output tables in Latin American countries", Structural Interdependence and Economic Development, T. Barna (ed.), London, Palgrave Macmillan. (1960), "Some applications of the input-output model to the Argentine economy", Economic Bulletin for Latin America, vol. 5, No. 1, Santiago, Economic Commission for Latin America (ECLA). (1958), "La utilización del modelo de insumo-producto en las proyecciones de la economía argentina", Desarrollo Económico: Revista de Ciencias Sociales, vol. 1, No. 1.

Balboa, M. and A. Fracchia (1959), "Fixed reproducible capital in Argentina, 1935-55", The Measurement of National Wealth, R. Goldsmith and C. Saunders (eds.), Chicago, Quadrangle Books.

Berlinski, J. and others (1964), "Metodología de las proyecciones del plan de desarrollo" [online] https://aaep. org.ar/anales/works/works1964/Berlinski.pdf.

Besa García, J. (1992), "Escritos de Manuel Balboa 1952-1976: bibliografía existente en la Biblioteca de la CEPAL" [online] https://repositorio.cepal.org/bitstream/handle/11362/3400/FILE\%20\%28147914\%29_ es.pdf?sequence $=1$ \&isAllowed $=y$.

Boianovsky, M. (2013), "The Economic Commission for Latin America and the 1950s' debate on choice of techniques", Review of Political Economy, vol. 25, No. 3.

Brodersohn, M. and A. Guisarri (1968), "Utilización del modelo de insumo-producto como instrumento de proyección en la Argentina", El Trimestre Económico, vol. 35, No. 140.

CECE (Centro de Estudiantes de Ciencias Económicas) (1962), "Guía del estudiante", Buenos Aires.

Chirom, J. (1985), "La profesión contable: ejercicio, antecedentes, marco legal", thesis on professional practice, Buenos Aires.

Cuello, R. and C. Tandeciarz (1964), Programas de desarrollo económico: introducción a su estudio, Buenos Aires, Editorial Universitaria de Buenos Aires (Eudeba).

Dagnino Pastore, J. and M. Fernández López (1988), "Los economistas en el gobierno argentino", Crónicas económicas: Argentina, 1969-1988, J. Dagnino Pastore (ed.), Buenos Aires, Editorial Crespillo.

De Pablo, J. (1995), Apuntes a mitad de camino: economía sin corbata, Buenos Aires, Ediciones Macchi.

Dieulefait, C. (1958), "El modelo de insumo-producto y el problema de inversión", Revista de Ciencias Económicas, vol. 4, No. 3.

ECLA (Economic Commission for Latin America) (1961), Report on the Joint ECLAVBTAO Economic Development Training Programme (E/CN.12/588), Santiago, March.

(1959a), "El desarrollo económico de la Argentina", Analyses and Projections on Economic Development, vol. 5 (E/CN.12/429/Add.3/Rev.1), Mexico City, August.

(1959b), Report on the Joint ECLAVTAA Economic Development Training Programme (E/CN.12/523), Santiago, March.

(1958), Manual on Economic Development Projects (E/CN.12/426/Add.1/Rev.1), New York.

(1957), Report on the ECLAVTAA Economic Development Training Programme (E/CN.12/433), Santiago, April.

(1955), "An introduction to the technique of programming", Analyses and Projections on Economic Development, vol. 1 (E/CN.12/363), New York, June.

(1953), Preliminary Study on the Technique of Programming Economic Development (E/CN.12/292), Santiago, March.

(1951), Theoretical and Practical Problems of Economic Growth (E/CN.12/221), New York, May.

ECLA/ILPES (Economic Commission for Latin America/Latin American and Caribbean Institute for Economic and Social Planning) (1963), "Progress in planning in Latin America", Economic Bulletin for Latin America, vol. 8, No. 2, Santiago, Economic Commission for Latin America (ECLA), October.

Fernández Balmaceda, R. and others (1965), "Construcción de modelos de insumo-producto en la República Argentina", Desarrollo Económico: Revista de Ciencias Sociales, vol. 5, No. 17/19.

Furtado, C. (1988), La fantasía organizada, Buenos Aires, Editorial Universitaria de Buenos Aires (Eudeba).

Grupe, H. and O. Cornblit (1960), Curso intensivo de capacitación sobre problemas de desarrollo económico, Mendoza, Federal Investment Council (FIC). 
ILPES (Latin American and Caribbean Institute for Economic and Social Planning) (2012a), "Evolución y orientaciones del Instituto Latinoamericano de Planificación Económica y Social: nota del director general", Los fundamentos de la planificación del desarrollo en América Latina y el Caribe: textos seleccionados del ILPES (1962-1972), ECLAC Books, No. 116 (LC/G.2552-P), R. Martner and J. Máttar (comps.), Santiago, Economic Commission for Latin America and the Caribbean (ECLAC).

(2012b), "Evolución y perspectivas de los procesos de planificación en América Latina", Los fundamentos de la planificación del desarrollo en América Latina y el Caribe: textos seleccionados del ILPES (1962-1972), ECLAC Books, No. 116 (LC/G.2552-P), R. Martner and J. Máttar (comps.), Santiago, Economic Commission for Latin America and the Caribbean (ECLAC).

Jáuregui, A. (2014), "La planificación en la Argentina del desarrollo (1955-1973)", Temas de historia argentina y americana, No. 22.

(2013), "La planificación en la Argentina: el CONADE y el PND (1960-1966)", Anuario del Centro de Estudios Históricos "Prof. Carlos S. A. Segreti", No. 13.

Leontief, W. (1951), The Structure of American Economy, 1919-1939: An Empirical Application of Equilibrium Analysis, New York, Oxford University Press.

Reig, E. (1958), "Notas universitarias: reforma del plan de estudios. La enseñanza universitaria en EE.UU.", Revista de Ciencias Económicas, vol. 4, No. 2.

San Miguel, M. and others (1961), "Examen crítico de la actual situación económica del país en el aspecto relacionado con la estabilidad monetaria y la producción", Revista de Ciencias Económicas, vol. 49, No. 16.

Sunkel, O. (2000), "La labor de la CEPAL en sus primeros dos decenios", La CEPAL en sus 50 años: notas de un seminario conmemorativo, ECLAC Books, No. 54 (LC/G.2103-P), Santiago, Economic Commission for Latin America and the Caribbean (ECLAC), July.

Toranzos, F. (1962), "Modelo lineal de expansión económica equilibrada", Revista de Ciencias Económicas, No. 18.

UBA (University of Buenos Aires) (1975), "Programa de la materia 315, 'Desarrollo Económico'” [online] http:// biblio.econ.uba.ar/cgi-bin/koha/opac-detail.pl?biblionumber=192679\&query_desc=ti\%2Cwrdl\%3A\%20 programa\%20desarrollo\%20econ\%C3\%B3mico.

(1973), "Programa de la materia 315, 'Desarrollo Económico'” [online] http://biblio.econ.uba.ar/cgi-bin/ koha/opac-detail.pl?biblionumber=192678\&query_desc=ti\%2Cwrdl\%3A\%20programa\%20desarrollo\%20 econ\%C3\%B3mico.

(1967), "Programa Seminario sobre política del desarrollo económico", Buenos Aires, Faculty of Economic Sciences.

(1965), "Curso intensivo de capacitación sobre problemas del desarrollo económico", Buenos Aires, Faculty of Economic Sciences.

(1964), "Curso intensivo de capacitación sobre problemas del desarrollo económico: elementos de contabilidad general, contabilidad nacional", Buenos Aires, Faculty of Economic Sciences.

(1963a), "Curso intensivo de capacitación sobre problemas del desarrollo económico", Buenos Aires, Faculty of Economic Sciences.

(1963b), "Programa Seminario sobre política del desarrollo económico", Buenos Aires, Faculty of Economic Sciences. 